\title{
Polymerase Chain Reaction (PCR), Immunoassay dan Respon Imunitas Penderita SARS nCoV-2, Sebuah Narasi Review (studi literatur)
}

\author{
Asryadin $^{1 *}$, Farhatush Shoalihat $^{1}$, M. Irfan ${ }^{2}$ \\ ${ }^{1}$ Microbiologist at Bima City Health Department, Bima City, West Nusa Tenggara, Indonesia. \\ ${ }^{2}$ Lecturer at STISIP and Legislative at Bima City Government \\ *E-mail : baekadhin@yahoo.co.id
}

Rekam Jejak Artikel:

Diterima : 15/12/2020

Disetujui : 10/04/2021

\begin{abstract}
The number of confirmed positive cases of SARS nCoV-2 in NTB Province based on data dated December 10, 2020 reached 4,987 cases with 144 patients dying, while in Bima City there were 455 positive cases with 13 patients dying. The key aspects of limiting the spread of the virus are ensuring fast and accurate diagnosis of viral infections and providing the appropriate type of quarantine for infected patients. Detection methods with reverse transcription-quantitative PCR (RT-qTPCR) often fail to detect the virus if specimen collection is not correct. This is because viral load is low at an early stage, viral load is suppressed by the host's immune system or samples taken at a later stage of the course of the disease. Serological testing is expected to serve as a faster diagnostic approach when there are limitations to the PCR examination of nucleic acids. The purpose of writing is to add references to readers regarding the SARS nCov-2 detection method, along with the advantages and disadvantages of this method and the immune response that is formed in post-infection patients. The writing method used is in the form of a review of several related scientific journals. Based on the review, the results and conclusions were obtained, namely that various detection methods for SARS nCoV-2 were carried out such as RT-qPCR and qualitative immunoassays (Rapid Test) and quantitative (ELISA, CLIA and GICA). SARS nCoV-2 is detected from the first week after exposure and the immune system in the human body will begin to form antibodies (IgM and $\operatorname{IgG}$ ) in response to the body's defense against the virus. Cytokine responses and lung damage are indications of a viral infection that can cause severe damage and even death in the event of acute respiratory distress syndrome caused by disruption of hyaluronan regulation.
\end{abstract}

Key Words : PCR, Immune Response, SARS nCoV-2, SARS nCoV-2 test in Bima City

\section{Abstrak}

Jumlah kasus terkonfirmasi positif SARS nCoV-2 di Provinsi NTB berdasarkan data pertanggal 10 Desember 2020 mencapai 4.987 kasus dengan 144 pasien meninggal, sedangkan di Kota Bima terdapat 455 kasus positif dengan 13 pasien meninggal. Aspek kunci untuk membatasi penyebaran virus adalah memastikan diagnosa cepat dan akurat terhadap infeksi virus dan memberikan jenis karantina yang sesuai bagi pasien terinfeksi. Metode deteksi dengan Reverse transcription- quantitative PCR (RT-qTPCR) sering gagal untuk mendeteksi virus jika pengambilan spesimen tidak tepat. Hal ini dikarenakan viral load rendah pada stadium awal, viral load disupresi imun host atau spesimen diambil pada tahap terakhir dari perjalanan penyakit. Tes serologis diharapkan berfungsi sebagai pendekatan diagnosa yang lebih cepat ketika terdapat limitasi pada pemeriksaan asam nukleat dengan PCR. Tujuan penulisan adalah menambah referensi bagi pembaca mengenai metode deteksi SARS nCov-2, berikut kekurangan dan kelebihan metode tersebut serta respon imunitas yang terbentuk pada penderita pasca infeksi. Metode penulisan yang digunakan adalah dalam bentuk review beberapa jurnal ilmiah terkait. Berdasarkan review tersebut diperoleh hasil dan simpulan yaitu berbagai metode deteksi SARS nCoV-2 dilakukan seperti RT-qPCR dan immunoassay kualitatif (Rapid Test) serta kuantitatif (ELISA, CLIA serta GICA). SARS nCoV-2 terdeteksi sejak minggu pertama setelah terpapar dan sistem imun dalam tubuh manusia akan mulai membentuk antibodi (IgM dan $\operatorname{IgG}$ ) sebagai respon pertahanan tubuh terhadap virus. Respon sitokin dan kerusakan paru paru merupakan indikasi infeksi virus yang dapat menyebakan kerusakan yang parah bahkan kematian apabila terjadi sindrom gangguan pernapasan akut yang disebabkan karena terjadinya gangguan regulasi hyaluronan.

Kata kunci : PCR, Respon Imun, SARS nCoV-2, Pemeriksaan SARS nCoV-2 di Kota Bima. 


\section{PENDAHULUAN}

Pandemi penyakit coronavirus 2019 (SARSNCOV-2) masih terus melanda sebagian besar populasi manusia di dunia. Pengetahuan tentang tes diagnostik untuk sindrom pernafasan akut yang disebabkan oleh coronavirus 2 (SARS-nCoV-2) terus berkembang dan harus diikuti dengan pemahaman dan interpretasi yang jelas, akurat dan tepat (Nandini et al., 2020). Diagnosis laboratorium termasuk SARSNCOV-2 dapat dilakukan dengan mendeteksi materi genetik virus, mendeteksi antibodi yang menetralkan partikel virus, mendeteksi epitop virus dengan antibodi (pengujian serologis), atau kultur dan isolasi partikel virus yang tentu memiliki keterbatasan masing-masing (Junxiong et al., 2020).

Data kasus COVID-19 di Indonesia berdasarkan informasi Gugus Tugas Percepatan Penanganan SARS-NCOV-2 per tanggal 12 Desember 2020 tercatat sejumlah 617,820 kasus terkonfirmasi positif dengan angka kesembuhan sebanyak 505,836 kasus dan 18,819 pasien meninggal, sementara di Provinsi NTB berdasarkan data pertanggal 10 Desember 2020, jumlah kasus terkonfirmasi positif mencapai 4.987 kasus dengan 144 pasien meninggal, sedangkan Kota Bima menyumbang 455 kasus positif dengan 13 pasien meninggal (Gugus Tugas SARSNCOV-2 Prov. NTB., 2020).

Persentase laki-laki pada kasus SARS-NCOV2 dengan kondisi parah dan kritis lebih tinggi daripada perempuan dengan persentasi kesembuhan yang maksimal terjadi pada kasus ringan (tanpa comorbid) dengan tingkat antibodi IgG lebih tinggi dan level IgM menurun secara bertahap ketika pasien dinyatakan sembuh (Hongyan et al., 2020).

Aspek kunci untuk membatasi penyebaran virus adalah memastikan diagnosa cepat dan akurat terhadap infeksi virus dan memberikan jenis karantina yang sesuai bagi pasien terinfeksi. Metode deteksi dengan Reverse Transcriptase qPCR sering gagal untuk mendeteksi infeksi virus jika pengumpulan spesimen tidak tepat Hal ini dikarenakan viral load rendah pada stadium awal, viral load mensupresi imun host atau spesimen diambil pada tahap terakhir dari perjalanan infeksi ( $\mathrm{Na}$ et al., 2020) sehingga diperlukan metode deteksi yang cepat dan akurat. Tes serologis selain sebagai tes skrining adanya respon imunitas terhadap infeksi (antigen maupun antibodi), namun juga diharapkan berfungsi sebagai pendekatan diagnosa yang lebih cepat ketika terdapat limitasi pada pemeriksaan asam nukleat dengan PCR terutama pada immunoassay kuantitatif yang sangat diperlukan pada penentuan prognosis terapi yang tepat (Fei et al. 2020). Hal yang perlu menjadi perhatian pada pemeriksaan berbasis serologi termasuk pada pemeriksaan SARS-NCOV-2 adalah perlunya mempelajari respon imun yang terbentuk pasca infeksi virus yang kemungkinan berbeda pada setiap manusia. Perbedaan respon imunitas pada setiap manusia dapat terjadi karena sistim imunitas yang melibatkan banyak aspek termasuk sel sistim imun berbeda pada setiap manusia. Respon sitokin dan kemokin, sel yang mempresentasikan antigen (APC), faktor usia dll menyebabkan terjadinya perbedaan sistim imun setiap manusia (Yufang et al., 2020).

\section{METODE}

Tulisan disusun dengan metode review menggunakan 24 artikel ilmiah yang diunduh dari beberapa web jurnal terindeks scopus dari tahun 2019 sampai tahun 2020. Seluruh jurnal di analisis sesuai tujuan untuk memperoleh informasi tentang polymerase chain ceaction (PCR), immunoassay dan respon imunitas penderita SARS nCoV-2. Analisis ditekankan untuk menjelaskan tentang SARS nCoV-2, jenis pemeriksaan: deteksi RNA virus dengan RTPCR, pemeriksaan laboratorium SARS-NCOV-2 berbasis serologi, nilai diagnostik uji. Selanjutnya dijelaskan respon imunitas yang terbentuk akibat infeksi SARS nCoV-2, sitokin dan kerusakan ParuParu, dan hyaluronan: penyebab potensial kematian.

\section{HASIL DAN PEMBAHASAN}

\section{SARS nCoV-2}

Sejak pertengahan Desember 2019 dan awal Februari 2020, SARS-nCoV-2 yang berasal dari Wuhan (Provinsi Hubei, Cina) (Junxiong et al., 2020) yaitu sebuah betacoronavirus, membentuk klade dalam subgenus sarbecovirus dari subfamili Orthocoronavirinae ( $\mathrm{Na}$ et al., 2019). Coronavirus adalah virus RNA yang memiliki panjang sekitar 72 $\mathrm{kb}$ dengan protein utama yaitu protein nukleokapsid $(\mathrm{N})$, protein spike (S), protein envelope (E) dan protein membran $(\mathrm{M})$ yang tersebar luas diantara manusia, mamalia lain, dan burung yang menyebabkan penyakit pernapasan, enterik, hati, dan neurologis. Enam spesies virus corona diketahui menyebabkan penyakit pada manusia. Empat virus 229E, OC43, NL63, dan HKU1 biasanya menyebabkan gejala flu biasa pada individu yang Immunocompromised. Dua jenis lainnya menyebabkan sindrom pernapasan akut parah coronavirus (SARSCoV) dan sindrom pernapasan Timur Tengah coronavirus (MERS-CoV) dan telah dikaitkan dengan penyakit yang terkadang berakibat fatal (Jie et al., 2019).

\section{Jenis Pemeriksaan}

a. Deteksi RNA virus dengan RT-PCR

Tes yang paling umum digunakan untuk diagnosis SARS-NCOV-2 telah dilakukan uji RTPCR menggunakan spesimen dari saluran pernapasan bagian atas dan bawah. Berbagai gen target RNA digunakan dan sebagian besar tes menargetkan 1 atau lebih gen envelope (E), nukleokapsid $(\mathrm{N})$, spike $(\mathrm{S})$, gen RdRp, dan gen ORF1. Kebanyakan uji menggunakan protein $\mathrm{N}$ dan $\mathrm{S}$ sebagai gen target (Nandini et al., 2020).

Pada sebagian besar orang dengan gejala SARS-NCOV-2, RNA virus diukur dengan ambang batas jumlah siklus $(\mathrm{Ct})$ yang terdeteksi sejak hari pertama gejala dan puncak dalam minggu pertama. Nilai $\mathrm{Ct}$ yang lebih rendah menunjukkan RNA virus yang lebih tinggi dan Nilai Ct kurang dari 40 secara klinis dilaporkan sebagai PCR positif. Konfirmasi 
hasil pemeriksaan positif mulai menurun pada minggu ke-3 dan selanjutnya menjadi tidak terdeteksi. Namun, pada kasus parah, kepositifan PCR dapat bertahan lebih dari 3 minggu setelah sakit (Roman et al., 2020).

RNA virus dalam beberapa kasus terdeteksi oleh RT-qPCR bahkan hingga minggu ke-6 setelah tes positif pertama. Beberapa kasus juga dilaporkan positif setelah 2 tes RT-qPCR negatif berturut-turut. Hal ini kemungkinan dapat terjadi karena pemeriksaan dengan RT-qPCR memiliki resiko kesalahan yang perlu dihindari dan menjadi perhatian khusus tenaga pemeriksa terutama untuk menghindari kekeliruan hasil karena kesalahan pengujian dan kualitas spesimen. Namun beberapa hal yang perlu diperhatikan juga adalah kemungkinan adanya infeksi ulang atau aktivasi ulang virus (Roman et al., 2020).

Konfirmasi hasil positif SARS nCov-2 pada pemeriksaan menggunakan metode RT qPCR memberikan hasil yang berbeda pada spesimen selain usap nasofaring. Hasil deteksi positif RT qPCR menurun lebih lambat dalam spesimen sputum dan kemungkinan dapat positif kembali setelah pemeriksaan dengan spesimen usap nasofaring negatif. Pada penelitian Shufa et al. (2020) yang mencoba menggunakan spesimen tinja menunjukkan bahwa hasil positif RT-qPCR dalam tinja diamati pada 55 dari 96 spesimen (57\%), namun hasil positif RTqPCR pada spesimen tinja tidak terkait dengan keparahan klinis dan bukan merupakan sampel standart pada deteksi SRAS nCoV-2.

Dalam penelitian Wenling et al. (2020) terhadap 205 pasien dengan konfirmasi positif SARSNCOV-2, RT-PCR positif tertinggi pada spesimen lavage bronchoalveolar (93\%), diikuti oleh sputum $(72 \%)$, swab orofaring $(63 \%)$, dan swab nasofaring (32\%). Hasil negatif palsu terutama terjadi karena waktu pengambilan spesimen yang tidak tepat serta kekurangan dalam teknik pengambilan spesimen, terutama pengambilan spesimen usap nasofaring yang disebabkan karena jumlah spesimen yang tidak adekuat karena swab dacron yang tidak sepenuhnya menjangkau spesimen nasofaring dan lain lain. Spesifisitas sebagian besar tes RT-qPCR adalah $100 \%$ (Nandini et al., 2020) karena menggunakan desain primer dan probe qPCR dari gen spesifik dikhususkan untuk urutan genom SARS-nCoV-2. Primer dan Probe PCR yang spesifik merupakan salah satu aspek penting dalam reaksi RT qPCR (Thermofisher, 2016).

Hasil palsu pada pemeriksaan RT qPCR dapat terjadi karena kesalahan teknis dan kontaminasi reagen (Nandini et al., 2020). Selain itu menurut Junxiong et al., (2020), Keterbatasan dari deteksi materi genetik adalah kurangnya pengetahuan tentang keberadaan materi genetik virus, potensi reaktivitas silang dengan genetik non-spesifik seperti dari family coronavirus lainnya serta jangka waktu singkat untuk deteksi akurat selama fase infeksi akut.

b. Pemeriksaan Laboratorium SARS-NCOV-2 berbasis serologi

Infeksi SARS-NCOV-2 juga dapat dideteksi secara tidak langsung dengan mengukur respon imunitas terhadap infeksi SARS-nCoV-2. Diagnosis serologis khususnya penting bagi pasien dengan penyakit ringan hingga sedang yang kemungkinan terlambat menunjukkan gejala (Nandini et al., 2020). Menurut $\mathrm{Na}$ et al., (2020), tes serologi dilakukan ketika metode deteksi dengan RT qPCR sulit dilakukan, misalnya karena keterbatasan sarana prasarana penunjang pemeriksaan berbasis molekuler pada daerah-daerah tertentu. Beberapa penelitian menunjukkan bahwa Tes serologis terutama dalam mendeteksi keberadaan IgM SARS nCoV-2 dapat memberikan sensitivitas dan masukan pemberian terapi pengobatan yang lebih tepat yang lebih baik dibandingkan dengan deteksi yang hanya mengandalkan pemeriksaan dengan metode RT qPCR saja. Hal ini sangat penting pada masa pandemi, dimana diagnosis yang tepat sangat penting untuk membatasi penyebaran virus dan meningkatkan keberhasilan terapi.

Penanda serologis infeksi SARS nCoV-paling awal adalah dengan mendeteksi keberadaan IgM yang biasanya muncul pada hari ke3-4 setelah infeksi, selain itu juga beberapa metode serologis langsung mendeteksi keberadaan total antibodi yang bisanya mulai meningkat pada minggu kedua setelah gejala (Bin et al., 2020). Meskipun IgM dan IgG ELISA telah terbukti positif bahkan sejak hari keempat setelah timbulnya gejala (Nandini et al., 2020). Pengujian imun untuk mengukur antibodi Anti-SARSnCoV-2 yang tersedia saat ini memiliki peran penting, terutama untuk $\operatorname{IgG}$ dan kombinasi kedua immunoglobulin ( $\operatorname{IgM}$ dan $\operatorname{IgA}$ ) yang menunjukkan kehadiran $90 \%$ secara keseluruhan selama infeksi berlangsung (Giuseppe et al., 2020). Penggunaan metode deteksi serogis dengan mendeteksi kehadiran antibodi (IgG, IgM atau total antibodi) merupakan pemeriksaan yang paling banyak digunakan selama pandemi untuk kegiatan skrining sebelum penggunaan metode serologis dengan mendeteksi antigen SARS nCoV-2 mulai digunaan saat ini.

Laju pembentukan antibodi berbeda pada setiap individu, sehingga waktu pengambilan spesimen untuk deteksi infeksi mikroorganisme termasuk SARS nCoV-2 ditentukan sesuai terbentuknya gejala (Li et al., 2020). Sebagian besar deteksi berbasis serologi menargetkan gen dari protein $\mathrm{S}$ dan $\mathrm{N}$. Kombinasi deteksi IgM dan IgG spesifik protein $\mathrm{N}$ dan $\mathrm{S}$ mampu mengidentifikasi hingga $75 \%$ pasien SARS-nCoV-2 pada minggu pertama setelah gejala (Baoqing et al., 2020) termasuk pemeriksaan menggunakan ELISA, Chemiluminescence Immunoassay (CLIA) dengan marker berupa derivative dari luminol dengan peroksidase dan $\mathrm{H} 2 \mathrm{O} 2$ (atau system enzimatik lainnya yang menghasilkan $\mathrm{H}_{2} \mathrm{O}_{2}$, seperti oksidase glukosa atau uricase) ditambah penambah (turunan dari Fenol, seperti p-iodofenol), maupun Gold Immunochromatograaphic Assay (GICA) yang menggunakan membran nitroselulose sebagai pembawa dan koloid emas berlabel antigen atau antibodi sebagai marker (Nisreen et al., 2020; Zu-Li et al., 2020). Nisreen et al., (2020) menyatakan bahwa antibodi sub unit $\mathrm{S} 1$ lebih spesifik dibandingkan protein $\mathrm{S}$, antigen terhadap sub unit $\mathrm{S} 1$ lebih spesifik 
pada deteksi SARS nCoV-2 serta antibodi terhadap protein subunit S1 dan Receptor Binding Domain (RBD) tidak muncul pada pasien non Covid.

Selain itu, protein nucleocapside (N) SARS nCoV-2 diproduksi secara melimpah selama infeksi berlangsung dan menunjukkan imunogenisitas yang kuat serta dapat bertindak sebagai antigen yang ideal untuk deteksi antibodi virus (Mustafa et al., 2015). Jenis pemeriksaan berbasis serologis dapat dilakukan dengan menggunakan teknik pengujian kualitatif seperti pemeriksaan tes rapid berbasis imunokromatografi yang memiliki peran penting dalam manajemen penyakit dan wabah sehingga memungkinkan pengawasan kesehatan masyarakat, upaya pencegahan dan pengendalian yang cepat dan akurat, namun tentu saja hasil positif (reaktif) tes rapid harus dikonfirmasi dengan pemeriksaan berbasis molekuler (RT qPCR). Transmisi dan cluster lokal dapat dicegah dan atau ditunda dengan cara mengisolasi kasus yang terkonfirmasi positif serta dengan menlakukan karantina dan pemantauan yang berkesinambungan pada kontak dekat penderita. Diagnosis cepat juga memfasilitasi intervensi kesehatan masyarakat spesifik lain seperti penutupan fasilitas dan area yang berisiko tinggi terkait dengan kasus yang terkonfirmasi untuk pengendalian infeksi yang cepat dan dekontaminasi lingkungan (Junxiong et al., 2020).

Selain itu, pemeriksaan serogis yang menggunakan teknik pengujian kuantitatif kedepannya juga sangat diperlukan mengingat keterbatasan sarana dan prasarana maupun keterbatasan hasil pemeriksaan berbasis asam nukleat (materi genetik) dengan alat PCR. Saat ini juga dikenal beberapa teknis immunoassay yang bersifat kuantitatif seperti ELISA, CLIA maupun GICA dengan nilai diagnostik yang baik (Zu-Li et al., 2020).

Hongyan et al. (2020) menjelaskan bahwa level antibodi IgM meningkat pada minggu pertama setelah infeksi dan terus meningkat hingga 2-3 minggu, kemudian menurun sesuai kondisi tubuh pasien. Pada kasus parah, kritis dan meninggal, level IgM lebih tinggi dibandingkan pada kasus ringan. Hal ini kemungkinan disebabkan oleh respon imun yang berlebihan yang merangsang pembentukan sel-sel dan protein sistim imun seperti sitokin (IL6) dan kemokin yang justru berbahaya bagi tubuh pasien dengan memberikan tingkat keparahan pada peradangan dan pasien disertai demam. Antibodi IgG terbentuk setelah 1 minggu terinfeksi dan mencapai puncak dalam waktu 3 minggu dan akan mencapai level tertinggi lebih dari 48 hari.

Baoqing et al. (2020) secara spesifik mendeteksi protein $\mathrm{S}$ dan protein $\mathrm{N}$ IgM pada pasien yang dirawat diruang ICU rumah sakit menyebutkan bahwa level N-IgM dan S-IgM terus meningkat hingga minggu ke-2 dan mengalami penurunan pada minggu ke-3, sedangkan $\mathrm{N}-\mathrm{IgG}$ dan $\mathrm{S}-\mathrm{IgG}$ terus meningkat. Penelitiannya menunjukkan bahwa pada pasien non-ICU memproduksi protein S-IgG, sedangkan pasien ICU memproduksi protein N-IgG. Perubahan IgM menjadi IgG pada pasien non-ICU lebih cepat dibandingkan dengan pasien ICU, hal ini mengindikasikan perubahan dari $\mathrm{S}-\operatorname{IgM}$ ke $\mathrm{S}-\mathrm{IgG}$ penting untuk membersihkan virus dan dapat digunakan sebagai indikator prognosis untuk memprediksi SARS-NCOV-2. Selanjutnya Baoqing et al. (2020) menyimpulkan bahwa antibodi terhadap protein $\mathrm{S}$ dapat memblok pengikatan protein $\mathrm{S}$ pada reseptor seluler ACE2 yang menjadi perantara pengikatan SARS-nCoV-2 dan masuk ke dalam sel target, sedangkan antibodi spesifik $\mathrm{N}$ tidak dapat memblok infeksi virus. Tingginya N-IgG daripada SIgG pada pasien ICU dapat disebabkan karena besarnya paparan virus pada masa awal infeksi dan jika $\mathrm{N}-\mathrm{IgG}$ terus meningkat artinya penyakit akan berkembang menjadi lebih parah.

Dalam penelitian Li et al. (2020), sekitar $22,0 \%$ pasien yang terkonfirmasi positif dengan $\mathrm{qPCR}$ ditemukan negatif dengan tes antibodi IgM. Tiga belas dari 18 pasien membentuk IgM kurang dari 6 hari setelah gejala yang mungkin dikarenakan antibodi tidak diproduksi dalam jumlah yang cukup. Dua pasien dari kasus berat dimana spesimen dikumpulkan pada hari ke19 dan 22 setelah gejala, kemungkinan kegagalan pembentukan antibodi pada pasien karena beratnya penyakit. Tiga spesimen terakhir dikumpulkan pada hari ke 9 dan 17 setelah gejala. Hal ini menunjukkan bahwa waktu perjalanan infeksi dan faktor host mempengaruhi respon imun.

Li et al. (2020) selanjutnya menjelaskan bahwa tes penanda antibodi yang paling sensitif adalah dengan mendeteksi total antibodi yang mulai meningkat pada minggu kedua setelah gejala. Serokonversi IgM dan IgG terjadi pada semua pasien antara minggu ketiga dan keempat timbulnya penyakit klinis seperti yang diukur pada 23 pasien oleh Kelvin et al. (2020) dan 85 pasien oleh Fei et al. (2020). Setelah itu $\operatorname{IgM}$ mulai menurun dan mencapai level lebih rendah pada minggu ke-5 dan hampir menghilang pada minggu ke-7. Sedangkan IgG bertahan lebih dari 7 minggu. Tes antibodi IgM dan IgG berbasis ELISA, CLIA maupun GICA memiliki spesifisitas lebih besar dari $95 \%$ untuk diagnosis SARS-NCOV-2. Perjalanan waktu kepositifan RT qPCR dan serokonversi dapat bervariasi pada anakanak dan kelompok usia lain, termasuk populasi besar individu tanpa gejala yang tidak terdiagnosis tanpa pengawasan aktif

Hal berbeda ditemukan oleh Fei et al. (2020) yang menyebutkan bahwa selama respon imun terhadap infeksi patogen, IgM biasanya diproduksi lebih awal dari IgG. Namun, IgM dan IgG terhadap SARS-nCoV-2 sama-sama terdeteksi sejak hari ke-4 setelah onset gejala, antibodi IgM dan IgG muncul lebih awal dibandingkan pada infeksi SARS pneumonia virus korona lainnya yang menunjukkan progresifitas SARS-NCOV-2 yang lebih tinggi dibandingan infeksi coronavirus lain. Lebih lanjut Fei et al. (2020) menegaskan bahwa pemeriksaan menggunakan ELISA, CLIA maupun GICA adalah pemeriksaan dengan sensitifitas dan spesifisitas yang baik dalam mendeteksi protein antibodi maupun antigen SARS-NCOV-2. 


\section{Nilai Diagnostik Uji}

Pada pemeriksaan berbasis asam nukleat, Nandini et al., (2020) menyebutkan bahwa sensitifitas dan spesifisitas uji berbasis molekuler dalam mendeteksi gen spesifik virus adalah $100 \%$ dengan ketentuan : uji harus menggunakan desain primer dan pelacak gen (probe) dari gen spesifik novel coronavirus (SARS-NCOV-2) pada pemeriksaannya.

Viljoen et al. (2005) menyebutkan bahwa Reverse Transcription Quantitiative PCR (RT-qPCR) termasuk yang digunakan dalam deteksi SARSNCOV-2 merupakan variasi teknik PCR konvensional yang umumnya digunakan untuk melakukan kuantifikasi DNA atau RNA dengan primer yang akan menentukan keberhasilan deteksi spesifik fragmen PCR menggunakan komponen primer spesifik. Sensitifitas dan spesifisitas qRT-PCR juga disebabkan oleh penggunaan probe berlabel reporter fluorescence (Thermofisher, 2016).

Nilai diagnostik pemeriksaan SARS-NCOV-2 berbasis serologis baik yang bersifat kualitatif seperti penggunaan rapid test dengan prinsip imunokromatografi maupun yang bersifat kuantitatif seperti metode ELISA, CLIA maupun GICA tergantung protein target deteksi dan kemampuan deteksi masing-masing alat yang digunakan maupun garis waktu pengambilan spesimen yang tepat. Beberapa penelitian menunjukkan nilai diagnostik yang berbeda-beda meskipun secara statistik tidak menunjukkan perbedaan yang signifikan. Seperti pada penelitian yang dilakukan oleh Kazuo et al. (2020) yang menyebutkan bahwa tes serologi berbasis imunokromatografi seperti pada rapid test memiliki sensitifitas yang tinggi untuk spesimen yang dikumpulkan >2 minggu setelah gejala, namun kurang sensitif untuk pasien bergejala 1 minggu, dan uji ini tidak dapat menggantikan RT-qPCR sebagai protokol penting diagnosa SARS-NCOV-2, namun tentu saja pemilihan rapid test dengan target protein gen yang tepat harus menjadi perhatian.

Selain itu, Tove et al. (2020) yang melakukan penelitian menggunakan rapid test dengan merek xxxxxxx, Lot: 2003242 di Zhejiang Orient Gene Biotech Co Ltd, Huzhou, Zhejiang, China menunjukkan sensitifitas yang baik bahkan menyerupai sensitifitas uji SARS-NCOV-2 berbasis serologis kuantitatif yang mencapai 97,5\%. Spesifisitas rapid test juga baik, ditunjukkan dengan tidak adanya hasil reaktif pada spesimen kontrol negatif. Sedangkan pada sebagian besar penelitian yang melakukan deteksi respon imun menggunakan tes serologis kuantitatif seperti penggunaan immunoassay metode ELISA, CLIA maupun GICA, sensitifitas dan spesifitas sangat baik dengan nilai diatas 95\% (Hongyan et al., 2020; Nisreen et al., 2020; Baoqing et al., 2020; Li et al., 2020; Nandini et al., 2020; Fei et al., 2020; Giuseppe et al., 2020).

\section{Respon imunitas yang terbentuk akibat infeksi SARS $n \mathrm{CoV}-2$}

Secara klinis, respon imun terhadap infeksi
SARS-nCoV-2 terdiri dari dua fase. Selama tahap inkubasi dan non severe, respon imun adaptif spesifik diperlukan untuk menghilangkan virus dan mencegah penyakit berkembang ke tahap yang lebih parah. Oleh karena itu, penguatan respon imun seperti sitokin (IL1,IL6, TNF dan IFN $\alpha$ ) penting. Untuk pengembangan respon imun endogen pada masa inkubasi dan tahap non-parah, host harus memiliki kondisi kesehatan yang baik dan latar belakang genetik yang sesuai (misalnya HLA) yang membentuk kekebalan antivirus. Perbedaan genetik berkontribusi pada keragaman respon imun terhadap patogen. Ketika respon imun terganggu, virus akan menyebar dan menyebabkan kerusakan besar pada jaringan, terutama pada organ yang memiliki ekspresi ACE2 yang tinggi seperti organ usus dan ginjal. Sel-sel yang rusak menginduksi terjadinya peradangan pada paruparu yang sebagian besar dimediasi oleh sitokin proinflamasi dan sel-sel granulosit (netrofil) yang selanjutnya menjadi penyebab utama gangguan pernapasan parah. Pada beberapa kasus, setelah keluar dari rumah sakit, beberapa pasien tetap/kembali positif. Hal ini menunjukkan bahwa respon kekebalan mungkin sulit untuk diinduksi setidaknya pada beberapa kasus pasien, dan vaksin mungkin tidak bekerja pada individu ini. Pada pasien yang dinyatakan sembuh dari tahap non-parah harus dipantau dengan melihat respon sel $\mathrm{T} / \mathrm{B}$. Respon sel $\mathrm{T}$ berupa aktifnya sel-sel respon imun terutama sel limfosit $\mathrm{T}$ sitotoksik sedangkan respon sel $\mathrm{B}$ berupa pemantauan kinetika pembentukan antibodi (Yufang et al., 2020).

\section{Sitokin dan Kerusakan Paru-Paru}

Cytokine release syndrome (CRS) dapat mempengaruhi pasien dengan kondisi parah. Netrofilia diserta limfositopenia sering muncul pada kasus parah. Kemunculan CRS akibat SARS-NCOV-2 dimediasi oleh sel lekosit selain sel limfosit T. Pada keadaan umum, pasien SARS-NCOV-2 menunjukkan peningkatan lekosit namun terjadi limfositopenia. Pada beberapa keadaan, infeksi SARS nCoV-2 dapat menyebabkan blokade dan atau menghalangi produksi mediator sitokin seperti IL6, IL1 dan TNF yang pada pasien tanpa kelainan respon imun, dapat menyebabkan peningkatan keparahan (severe) infeksi. Selain itu, C-Reaktif Protein yang diproduksi sebagai protein homopentamerik yang secara langsung dikaitkan dengan daerah inflamasi atau infeksi, meningkat dalam waktu 6-8 jam setelah adanya stimulus dan mencapai puncak setelah 36-50 jam. CRP dipertahankan selama masih terjadi peradangan dan atau nekrosis jaringan dan lalu menurun dengan cepat (PDS-PATKLIN, 2020). Pada suatu penelitian di China menunjukkan terapi menggunakan stem cell, namun hasil optimal belum diperoleh. Stem cell perlu diaktifkan oleh IFN gamma dengan menggunakan efek antiinflamasinya, hal ini kemungkinan tidak terjadi pada pasien parah, dimana sel $\mathrm{T}$ tidak diaktifkan dengan baik karena infeksi SARS-NCOV2. Belakangan ini, pendekatan tambahan terapi infeksi SARS nCoV-2 menggunakan plasma konvalesens 
marak digunakan. Pemberian plasma konvalesens, IVIG, kortikosteroid, antikoagulan, antiinflamasi lain seperti anti IL-6 diberikan dengan pertimbangan hatihati melalui diskusi dengan tim terapi pada fasilitas kesehatan (Pedoman tatalaksana pengobatan COVID19).

Selain penggunaan terapi tambahan dengan pemberian plasma konvalesens, untuk meningkatkan efektivitas, seseorang dapat dipertimbangkan untuk menggunakan Terapi Mesenchymal Stem Cell (MSC) dengan IFN $\gamma$ dengan/tanpa TNF atau IL-1. MSC dengan sitokin dapat lebih efektif dalam penekanan respon imun hiperaktif dan perbaikan jaringan. Kerusakan paru-paru merupakan rintangan utama untuk pemulihan pada pasien. Melalui produksi berbagai faktor pertumbuhan, MSCs dapat membantu memperbaiki jaringan paru-paru yang rusak. Pada hewan model dengan cedera paru yang diinduksi bleomycin, vitamin B3 (niacin atau nicotinamide) sangat efektif dalam mencegah kerusakan jaringan paru-paru. Mungkin menjadi pendekatan yang baik dengan memberikan suplemen (Yufang et al., 2020).

\section{Hyaluronan: Penyebab Potensial Kematian}

Respon imun bawaan terhadap kerusakan jaringan yang disebabkan oleh virus dapat menyebabkan sindrom gangguan pernapasan akut (ARDS), dimana gagal napas ditandai dengan gejala peradangan luas dan cepat di paru-paru dan kematian berikutnya. Gejala pasien ARDS termasuk pernapasan pendek/cepat, dan sianosis. CT scan menunjukkan bahwa ada bercak putih khas yang disebut "ground glass" yang mengandung cairan paru-paru yang kemungkinan merupakan hyaluronan (HA) yang berhubungan dengan ARDS.

Selama infeksi SARS termasuk SARS-NCOV2, Nelson et al. (2006) menyebutkan bahwa produksi dan regulasi hyaluronan telah rusak. Tingkat inflamasi sitokin (IL-1, TNF $\alpha$ ) tinggi pada paru-paru dan sitokin ini menginduksi Hialuronan/HA-sintase-2 (HAS2) di sel endotel $\mathrm{CD}_{31}{ }^{+}$yang berperan pada mekanisme pernapasan pada pasien terinfeksi, sel epitel Cellular Adhesion Molecule $\left(\mathrm{CAM}^{+}\right)$alveolar paru, dan fibroblas. Dengan menghambat produksi HA sangat menjanjikan dalam membantu pasien SARS-NCOV-2 bernafas. Secara umum, penanganan pasien SARSNCOV-2 dengan meningkatkan respon imun, yaitu fase perlindungan imunitas pertama dan yang kedua fase untuk merusak patogen yang dipicu oleh peradangan. Ketika terjadi batuk, pemberian vitamin B3 sangat melindungi paru-paru, dan ketika kesulitan bernapas dapat diberikan hyaluronidase untuk menghambat HAS2.

7. Penanganan Pemeriksaan Laboratorium SARSNCOV-2 berbasis serologi di Kota Bima NTB

Pemeriksaan laboratorium novel coronavirus (SARS-NCOV-2) di Kota Bima Nusa Tenggara Barat sendiri memiliki keterbatasan sarana dan prasarana laboratorium molekuler sehingga menjadi salah satu tantangan tersendiri dalam upaya optimalisasi deteksi SARS-NCOV-2 secara cepat. Deteksi dini masih mengandalkan pemeriksaan berbasis serologi sebelum dilakukan konfirmasi dengan pemeriksaan berbasis molekuler menggunakan RT-PCR melalui proses rujukan yang kemungkinan memiliki peluang besar yang menyebabkan kurang maksimalnya hasil pemeriksaan.

Kurang optimalnya hasil pemeriksaan melalui sistim rujukan dapat terjadi misalnya disebabkan spesimen yang tidak adekuat karena terjadi penurunan kualitas spesimen pada teknik pengepakan dan pengiriman spesimen ke laboratorium rujukan, selain itu dapat disebabkan karna estimasi waktu pemeriksaan spesimen yang melebihi batas waktu penyimpanan spesimen di laboratorium rujukan.

Penggunaan rapid test secara kualitatif yang berbasis pemeriksaan serologis menjadi andalan penting saat ini di Kota Bima yang diharapkan dapat membantu deteksi dini penderita dan calon penderita dalam rangka pengendalian dan pengawasan SARSNCOV-2, dimana saat ini penggunaan berbagai merek rapid test menjadi hal yang penting untuk diperhatikan terutama keunggulan nilai diagnostiknya.

Beberapa jenis rapid test yang digunakan untuk pemeriksaan hingga saat ini, masih menggunakan metode deteksi antibodi dengan spesimen serum/plasma dan whole blood. Fasilitas rapid test tersebut disediakan oleh Pemerintah Kota Bima melalui Dinas Kesehatan, dengan harapan, kedepannya rapid test yang digunakan selain mendeteksi antibodi juga disediakan untuk mendeteksi antigen SARS-NCOV-2 secara lebih spesifik. Keberadaan laboratorium molekuler (PCR) pun harus menjadi perhatian utama untuk meminimalisir kekeliruan hasil uji dan meningkatkan kualitas deteksi virus SARS-NCOV-2.

\section{SIMPULAN}

SARS-nCoV-2 menyebar dari manusia ke manusia dengan jumlah kasus yang terus meningkat. Berbagai metode deteksi SARS-NCOV-2 dilakukan seperti RT-PCR dan immunoassay kualitatif (Rapid Test) dan kuantitatif (ELISA, CLIA serta GICA). SARS-NCOV-2 terdeteksi sejak minggu pertama setelah terpapar dan sistem imun dalam tubuh manusia akan mulai membentuk antibodi (IgM dan $\mathrm{IgG}$ ) sebagai respon pertahanan tubuh terhadap virus. Hingga saat ini, deteksi SARS-NCOV-2 di Kota Bima NTB masih mengandalkan pemeriksaan serologi rapid test yang bersifat kualitatif dengan spesimen serum/plasma dan whole blood karena keterbatasan sarana dan prasarana laboratorium molekuler.

\section{DAFTAR REFERENSI}

Baoqing S., Feng, Y., Mo, X., Zheng, P., Wang, Q., Li, P., Peng, P., Liu, X., Chen, Z., Huang, H., Zhang, F., Luo, W., Niu, X., Hu, P., Wang, L., Peng, H., Huang, Z., Feng, L., Li, F., Zhang, F., Li, F., Zhong, N., and Chen, L., 2020. Kinetics of SARS-nCoV-2 specific IgM and $\mathrm{IgG}$ responses in SARS-NCOV-2 patients. 
Emerging Microbes \& Infections. Doi : 10.1080/22221751.2020.1762515.

Bin L., Li, T., Zheng, S., Su, Y., Li, Z., Liu, W., Yu, F., Ge, S., Zou, Q., Yuan, Q., Lin, S., Hong, C., Yao, X., Zhang, X., Wu, D., Zhou, G., Hou, W., Li, T., Zhang, Y., Zhang, S., Fan, J., Zhang, J., Xia, N., and Chen, Y., 2020. Serology characteristics of SARS-nCoV-2 infection since the exposure and post symptoms onset. medRxiv preprint. Doi : 10.1101/2020.03.23.20041707.

Fei X., Wang, X., He, X., Peng, Z., Yang, B., Zhang, J., Zhou, Q., Ye, H., Ma, Y., Li, H., Wei, X., Cai, P., and Ma, W.L., 2020. Antibody detection and dynamic characteristics in patients with SARS-NCOV-2. Published by Oxford University Press for the Infectious Diseases Society of America.

Giuseppe L., Salvagno, G.L., Pegoraro, M., Militello, V., Caloi, C., Peretti, A., Gaino, S., Bassi, A., Bovo, C., and Cascio, G.L., 2020. Assessment of immune response to SARS-nCoV-2 with fully automated MAGLUMI 2019-nCoV IgG and $\operatorname{IgM}$ chemiluminescence immunoassays. Clin Chem Lab Med. Doi : 10.1515/cclm2020-0473.

Gugus Tugas Percepatan Penanganan SARS-NCOV2, 2020 dan Provinsi NTB, 2020. Diakses pada tanggal 23 Agustus 2020 pukul 19.00 WIB. 2020 .

Hongyan H., Wang, T., Zhang, B., Luo, Y., Mao, L., Wang, F., Wu, S., and Sun, Z., 2020. Detection of $\operatorname{IgM}$ and $\operatorname{IgG}$ antibodies in patients with Coronavirus disease 2019. Clinical \& Translational Immunology. Doi: 10.1002/cti2.1136.

Jie C., Li, F., and Shi, Z.L., 2019. Origin and evolution of pathogenic coronaviruses. Nature Reviews. Doi : 10.1038/s41579-018-0118-9.

Junxiong P., Wang, M.X., Ang, I.Y.H., Tan, S.H.X., Lewis, R.F., Chen, J.I.P., Gutierrez, R.A., Gwee, S.X.W., Chua, P.E.Y., Yang, Q., Ng, X.Y., Yap., R.K.S., Tan, H.Y., Teo, Y.Y., Tan, C.C., Cook, A.R., Yap, J.C.H., and Hsu, L.Y., 2020. Potential rapid diagnostics, vaccine and therapeutics for 2019 novel Coronavirus (2019nCoV): a systematic review. Journal of Clinical Medicine. Doi : 10.3390/jcm9030623.

Kazuo I., Tabata, S., Ikeda, M., Noguchi, S., Kitagawa, Y., Matuoka, M., Miyoshi, K., Tarumoto, N., Sakai, J., Ito, T., Maesaki, S., Tamura, K., and Maeda T., 2020. Clinical evaluation of an immunochromatographic $\mathrm{IgM} / \mathrm{IgG}$ antibody assay and chest computed tomography for the diagnosis of SARS-NCOV2. Journal of Clinical Virology. Doi : 10.1016/j.jcv.2020.104393.
Kelvin K.W.T., Tsang, O.T., Leung, W.S., Tam., A.R., Wu, T.C., Lung, D.C., Yip, C.C.Y., Cai, J.P., Chan, J.M.C., Chik, T.S.H., Lau, D.P.L., Choi, C.Y.C., Chen, L.L., Chan, W.M., Chan, K.H., Ip, J.D., Ng, A.C.K., Poon, R.W.S., Luo, C.T., Cheng, V.C.C., Chan, J.F.W., Hung, I.F.N., Chen, H., and Yuen, K.Y., 2020. Temporal profiles of viral load in posterior oropharyngeal saliva samples and serum antibody responses during infection by SARSnCoV-2: an observational cohort study. Lancet Infect Dis. Doi : 10.1016/s14733099(20)30196-1.

Li G., Ren, L., Yang, S., Xiao, M., Chang, D., Yang, F., Cruz, C.S.D., Wang, Y., Wu,C., Xiao, Y., Zhang, L., Han, L., Dang, S., Xu, Y., Yang, Q.W., Xu, S.Y., Zhu, Y.C., Xu, Y.C., Jin, Q., Sharma, L., Wang, L., and Wang, J., 2020. Profiling early humoral response to diagnose novel Coronavirus disease (SARS-NCOV-2). Clinical Infetious Diseases. Doi : 10.1093/cid/ciaa310.

Mustafa S., Fletcher, T.E., Elaldi, N., Ozkurt, Z., Bastug, A., Yilmaz, G., Guner, R., Duygu, F., and Beeching, N.J., 2020. Antibody against nucleocapsid protein predicts susceptibility to human coronavirus infection. The British Infection Association. Published by Elsevier Ltd. Doi : 10.1016/j.jinf.2015.07.003.

Nandini S., Jeremiah, S.S., and Ryo, A., 2020. Interpreting diagnostic tests for SARS-nCoV-2. JAMA. Doi: 10.1001/jama.2020.8259.

Na Zhu., Zhang, D., Wang, W., Li, X., Yang, B., Song, J., Zhao, X., Huang, B., Shi, W., Lu, R., Niu, P., Zhan, F., Ma, X., Wang, D., Xu, W., Wu, G., Gao, G.F., and Tan, W., A novel coronavirus from patients with Pneumonia in China, 2019. The New England Journal of Medicine. Doi : 10.1056/NEJMoa2001017.

Nelson L., Chan, P.K.S., Ip, M., Wong, E., Ho, J., Ho, C., Cockram, C.S., dan Hui, D.S., 2006. AntiSARS-CoV IgG response in relation to disease severity of severe acute respiratory syndrome. Journal of Clinical Virology. Doi : 10.1016/j.jcv.2005.07.005.

Nisreen M.A.O., Muller, M.A., Li, W., Wang, C., GeurtsvanKessel, C.H., Corman, V.M., Lamers, M.M., Sikkema, R.S., de Bruin, E., Chandler, F.D., Yazdanpanah, Y., Hingrat, Q.L., Descamps, D., Houhou-Fidouh, N., Reusken, C.B.E.M., Bosch, B.J., Drosten, C., Koopmans, M.P.G., and Haagmans, B.L., 2020. SARS-nCoV-2 specific antibody responses in SARS-NCOV-2 patients. medRxiv preprint. Doi 10.1101/2020.03.18.20038059. 
PDS-PATKLIN (2020). Role Of CRP For Screening Respiratory Tract Infection, PDS-PATKLIN.

Roman W., Corman, V.M., Guggemos, W., Seilmaier, M., Zange, S., Muller, M.A., Niemeyer, D., Jones, T.C., Vollmar, P., Rothe, C., Hoelscher, M., Bleicker, T., Brunink,S., Schneider, J., Ehmann, R., Zwirglmaier, K., Drosten,C., and Wendtner, C., 2020. Virological assessment of hospitalized patients with COVID-2019. Nature. Doi : 10.1038/s41586-020-2196-X

Shufa Z., Fan, J., Yu, F., Feng, B., Lou, B., Zou, Q., Xie, G., Lin, S., Wang,R., Yang,X., Chen, W., Wang, Q., Zhang, D., Liu, Y., Gong, R., Ma, Z., Lu, S., Xiao, Y., Gu, Y., Zhang, J., Yao, H., Xu, K., Lu, X., Wei, G., Zhou, J., Fang, Q., Cai, H., Qiu, y., Sheng, J., Chen, Y., dan Liang, T., 2020. Viral load dynamics and disease severity in patients infected with SARS-nCoV2 in Zhejiang province, China, January-March 2020: retrospective cohort study. BMJ. Doi: 10.1136/bmj.m1443.

Thermofisher. Real-time PCR handbook. 2016. Applied biosystem, pp. 2-68

Tove H., Nissen, K., Krambrich, J., Ronnberg, B., Akaberi, D., Esmaeilzadeh, M., Salaneck, E., Lindahl, J., and Lundkvist, 2020. A., Evaluation of a SARS-NCOV-2 IgM and IgG rapid test; an efficient tool for assessment of past exposure to SARS-nCoV-2. Infection Ecology \& Epidemiology. Doi: 10.1080/20008686.2020.1754538.

Viljoen Gerrit, J., Louis, H.N., and John, R.C., 2005. Molecular Diagnostic PCR Handbook. Springer, pp. 1-260

Wenling W., Xu, Y., Gao, R., Lu, R., Han, K., Wu, G., and Tan, W., 2020. Detection of SARS$\mathrm{nCoV}-2$ in different types of clinical specimens. JAMA. Doi: 10.1001/jama.2020.3786.

Yufang S., Wang, Y., Shao, C., Huang, J., Gan, J., Huang, X., Bucci, E., Piacentini, M., Ippolito, G., and Melino, G., 2020. SARS-NCOV-2 infection: the perspectives on immune responses. Cell Death \& Differentiation. Doi : 10.1038/s41418-020-0530-3.

Zu-Li Z., Hou, Y.L., Li, D.T., and Li, F.Z., 2020. Diagnostic efficacy of anti-SARS-nCoV-2 IgG/IgM test for SARS-NCOV-2: a metaanalysis. Doi : 10.1002/jmv.26211. 